\title{
horticultura
brasileira
}

SOUZA FILHO, AL; OLIVEIRA, FHT; PRESTON, W; SILVA, GF; CARVALHO, SL. 2016. Nitrogen and phosphate fertilizer on green corn grown in succession to the melon crop. Horticultura Brasileira 34: 392-397. DOI - http://dx.doi.org/10.1590/S0102-05362016003014

\section{Nitrogen and phosphate fertilizer on green corn grown in succession to the melon crop}

\author{
Antonio L Souza Filho'; Fábio HT Oliveira'; Welka Preston ${ }^{1}$; Gerônimo F Silva ${ }^{2}$; Simplício L Carvalho ${ }^{1}$ \\ ${ }^{1}$ Universidade Federal Rural do Semi-Árido, Dept. Ciências Ambientais e Tecnológicas (UFERSA), Mossoró-RN, Brasil; alisboa70@, \\ yahoo.com.br; fabio@ufersa.edu.br; welkapreston@hotmail.com; simpliciolyra@gmail.com; ${ }^{2}$ Universidade Federal Rural de Pernambuco, \\ Dept. Eng. Agrícola (UFRPE), Recife-PE, Brasil; agrogefe@yahoo.com.br
}

\begin{abstract}
Melon producers, in Chapada do Apodi, Rio Grande do Norte State, Brazil, located between the states of Ceará and Rio Grande do Norte, have cultivated corn in succession to the melon crop. However, this crop rotation is not yet evaluated on the extent to which the residual effect of nitrogen and phosphate fertilization carried out in melon can supply partially or completely the corn demands of nitrogen and phosphorus. This work aimed to evaluate the effect of nitrogen $(\mathrm{N})$ and phosphorus $(\mathrm{P})$ in the production of corn in succession to the cultivation of melon (Cucumis melo) irrigated in an Alkaline Inceptisol of Chapada do Apodi. Ten treatments from the combinations between five $\mathrm{N}$ rates $(0 ; 45 ; 90 ; 160$ and $220 \mathrm{~kg} / \mathrm{ha})$ and four levels of $\mathrm{P}_{2} \mathrm{O}_{5}(0 ; 40 ; 80$; and $120 \mathrm{~kg} / \mathrm{ha})$ were compared. The experimental design was a randomized block with four replications. The corn cultivar was the hybrid AG 1051 and the characteristics evaluated were number and total weight of ears, number and weight of marketable unhusked ears and concentrations of $\mathrm{N}$ and $\mathrm{P}$ in plant and $\mathrm{P}$ in the soil. This study also estimated critical levels of $\mathrm{N}$ and $\mathrm{P}$ in the plant and $\mathrm{P}$ in the soil. Producing green corn in succession to melon is viable, in this experiment conditions, without application of nitrogen and phosphorus to the soil. However, for maximum corn productivity, application of $90 \mathrm{~kg} / \mathrm{ha} \mathrm{N}$ combined with $40 \mathrm{~kg} / \mathrm{ha} \mathrm{P}_{2} \mathrm{O}_{5}$ is recommended. The average critical level of $\mathrm{N}$ and $\mathrm{P}$ in the plant for corn production was 32.29 and $4.31 \mathrm{~g} / \mathrm{kg}$, respectively. This value for $P$ in the soil was $20.7 \mathrm{mg} / \mathrm{dm}^{3}$.
\end{abstract}

Keywords: Cucumis melo, Zea mays, continuous cultivation, fertilization, residual effect.

\section{RESUMO}

Adubação nitrogenada e fosfatada em milho verde cultivado em sucessão ao meloeiro

Os produtores de melão na Chapada do Apodi, localizada entre os Estados do Ceará e do Rio Grande do Norte, têm cultivado o milho verde como cultura de sucessão ao meloeiro. Contudo, nessa sucessão de culturas ainda não se avaliou até que ponto o efeito residual das adubações nitrogenadas e fosfatadas realizadas no meloeiro pode suprir parcial ou totalmente as demandas de nitrogênio e de fósforo do milho verde. Neste trabalho objetivou-se avaliar o efeito de doses de nitrogênio $(\mathrm{N})$ e de fósforo $(\mathrm{P})$ na produção de milho verde, em sucessão ao cultivo de melão (Cucumis melo) irrigado, em um Cambissolo Alcalino da Chapada do Apodi. Foram comparados dez tratamentos resultantes de combinações entre cinco doses de $\mathrm{N}$ $(0,45,90,160$ e $220 \mathrm{~kg} / \mathrm{ha})$ e quatro doses de $\mathrm{P}_{2} \mathrm{O}_{5}(0,40,80$ e 120 $\mathrm{kg} / \mathrm{ha}$ ). O delineamento experimental foi de blocos ao acaso com quatro repetições. A cultivar utilizada para produção de milho verde foi o híbrido AG 1051 e as características avaliadas foram número e peso total de espigas, número e peso de espigas comercializáveis empalhadas e teores de $\mathrm{N}$ e de $\mathrm{P}$ na planta e $\mathrm{P}$ no solo. Também foram estimados os níveis críticos de $\mathrm{N}$ e de $\mathrm{P}$ na planta e de $\mathrm{P}$ no solo. Nas condições deste experimento, é viável produzir milho verde em sucessão ao cultivo de melão sem a aplicação de nitrogênio e de fósforo no solo. Porém, para obtenção de uma produtividade de milho verde ainda maior, e com um gasto mínimo de fertilizantes, recomenda-se a aplicação de $45 \mathrm{~kg} /$ ha de $\mathrm{N}$ na ausência de adubação fosfatada, ou $40 \mathrm{~kg} / \mathrm{ha}$ de $\mathrm{P}_{2} \mathrm{O}_{5}$ na ausência de adubação nitrogenada. $\mathrm{O}$ nível crítico médio de $\mathrm{N}$ e de $\mathrm{P}$ na planta para produção de milho verde foi de 32,29 e $4,31 \mathrm{~g} / \mathrm{kg}$, respectivamente, e para o P no solo foi de $20,7 \mathrm{mg} / \mathrm{dm}^{3}$.

Palavras-chave: Cucumis melo, Zea mays, cultivo sucessivo, fertilização, efeito residual.

(Recebido para publicação em 21 de agosto de 2014; aceito em 8 de janeiro de 2016)

(Received on August 21, 2014; accepted on January 8, 2016)

$\mathrm{C}$ orn (Zea mays) is grown in several regions of the world. In Brazil, besides its high prestige in agribusiness, corn is one of the crops most cultivated by family agriculture, both for subsistence and for local sale.

In this sense, due to the evident agriculture importance of this crop and current call for a more sustainable agriculture, various mechanisms have been used to maximize production without damaging the soil and the environment around. Among these mechanisms, crop succession, an alternative practice to monocropping. This mechanism has been used, for a long time, by farmers, who, normally, have no sufficient information related to how they can use the remaining fertilizer in the soil to reduce production costs.

The benefits of an appropriate crop 
succession include an improvement in soil resistance to erosion and fertility, as well as direct and indirect agronomic benefits (Franchini et al., 2011). The crop succession offers some advantages such as exploitation and input of differentiated organic matter in the soil by the root system, better conditions for developing predators, alternation of nutrient and water exploitation in different soil layers, reduction of soil compaction and differentiated product offerings to the market (Silva et al., 2011).

Nitrogen and phosphorus are the two nutrients that most limit grain production in Brazilian natural conditions, especially concerning the production of Poaceae (grasses) (Fidelis et al., 2009). In corn crop, $\mathrm{N}$ is required in the largest quantity, among the mineral nutrients, this element being the most limiting one for production of grasses. This makes the production more expensive, since $\mathrm{N}$ is very important in the plant biochemical processes (Scudeler et al., 2011).

In relation to $P$, the corn crop generally responds to planting phosphorus fertilization and to residual effects of phosphorus fertilization carried out on the previous crops (Silva et al., 2000). Also, according to the authors, when the previous crops are fertilized properly, the residual effects of the phosphorus fertilizers are remarkably expressed. Filgueira (1982) verified satisfactory production of marketable corn ears, grown after stalked tomato plants, using only the fertilization residues.

Chapada do Apodi, region located in Rio Grande do Norte State border with the state of Ceará, stands out in the irrigated melon production during dry season (second semester of the year). However, during rainy season (first semester) many areas of melon are not cultivated since the weather conditions promote the attack of Acidovorax citrulli, a major pathogen for the crop, which causes blotch or bacterial blotch of melon (Oliveira et al., 2007b). Thus, the producers of the region have been seeking alternative crops for the rainy season, which provides income besides promoting the break of main cycles of pests and diseases of melon as well as the cycling of nutrients.

In melon crop, the use of high doses of fertilizers is necessary, since this crop shows short cycle and is highly demanding in respect to nutrients (Filgueira, 2009). As a result, successor crops, such as the sweet corn, may use residues of these high fertilizations.

According to the above mentioned and considering the lack of results of researches on the use of nutrients left in the soil after cultivation of melon in $\mathrm{RN}$, and, especially in Chapada do Apodi, this work aimed to study the effect of doses of $\mathrm{N}$ and $\mathrm{P}$ in the production of sweet corn, in succession to irrigated melon, in an Alkaline Inceptisol.

\section{MATERIAL AND METHODS}

\section{Description of the experimental field}

The experiment was carried out at Chapada do Apodi, in the agricultural year 2012, in a private agricultural property, cultivated for ten years with melon on condition of monocropping. In succession to this cultivation, corn (Zea mays) was grown for the first time. This experimental field is located in the municipality of Quixeré, Ceará State, $80 \mathrm{~km}$ from Mossoró ( $5^{\circ} 05^{\prime} 37^{\prime}$ 'S, 3748'2'W, 124 m elevation).

The local climate, where the experiment was carried out, is hot semiarid type, presenting a period of irregular rainfall from February to May, and a period of dry weather from June to January, with average annual rainfall $696 \mathrm{~mm}$, annual average temperature around $27.4^{\circ} \mathrm{C}$, annual average relative humidity $70 \%$.

The experiment was conducted on a soil classified as eutrophic haplic Inceptisol, sandy clay texture, derived from limestone and flat topography (Embrapa, 2013), and showed the following chemical and physical characteristics $(0-20 \mathrm{~cm})$ before the experiment implementation: $\mathrm{pH}=7.12$ $\left(\mathrm{H}_{2} \mathrm{O}\right) ; 17.3 \mathrm{~g} / \mathrm{kg} \mathrm{M.O;} 0.35 \mathrm{~g} / \mathrm{kg} \mathrm{N}$ total $15.2 ; 290.3 ; 105.9 \mathrm{mg} / \mathrm{dm}^{3} \mathrm{P}, \mathrm{K}, \mathrm{Na}$, respectively; $11.8 ; 2.4 ; 0.0 ; 0.0 \mathrm{cmol}_{\mathrm{c}} /$ $\mathrm{dm}^{3} \mathrm{Ca}, \mathrm{Mg}, \mathrm{Al}$ and $\mathrm{H}+\mathrm{Al}$, respectively, and granulometric values of $500 \mathrm{~g} / \mathrm{kg}$ sand, $120 \mathrm{~g} / \mathrm{kg}$ silt and $380 \mathrm{~g} / \mathrm{kg}$ clay, according to Embrapa (2011).

\section{Experimental design and treatments}

The experimental design was randomized blocks, with four replications, totalizing 10 treatments. The treatments consisted of the combination of four $\mathrm{P}_{2} \mathrm{O}_{5}$ doses $(0 ; 40$; 80 and $120 \mathrm{~kg} / \mathrm{ha})$ with five doses of $\mathrm{N}$ $(0 ; 45 ; 90 ; 160$ and $220 \mathrm{~kg} / \mathrm{ha})$. In the three first treatments, three doses of $\mathrm{N}$ were applied $(0 ; 45$ and $90 \mathrm{~kg} / \mathrm{ha})$ in the absence of phosphate fertilizer (zero dose of $\left.\mathrm{P}_{2} \mathrm{O}_{5}\right)$, in the treatments 4 to 8 five doses of $\mathrm{N}$ were applied $(0 ; 45$; $90 ; 160$ and $220 \mathrm{~kg} / \mathrm{ha}$ ) in the presence of phosphate fertilizer $\left(40 \mathrm{~kg} / \mathrm{ha} \mathrm{P}_{2} \mathrm{O}_{5}\right)$, and in the two last treatments two $\mathrm{P}_{2} \mathrm{O}_{5}$ doses were applied (80 and $120 \mathrm{~kg} / \mathrm{ha}$ $\mathrm{P}_{2} \mathrm{O}_{5}$ ) in the presence of $90 \mathrm{~kg} / \mathrm{ha} \mathrm{N}$. Thus, the ten treatments consisted of the following combinations of doses ( $\mathrm{kg} /$ ha) of N-P $\mathrm{O}_{5}: 0-0 ; 45-0 ; 90-0 ; 0-40$; $45-40$; 90-40;160-40; 220-40; 90-80 and 90-120.

Doses of $\mathrm{N}$ were divided, applying $20 \%$ of the $\mathrm{N}$ dose during corn sowing and the remaining $80 \%$ in top dressings, at 25 and 45 days after the plant emergence. The doses of other nutrients $\left(\mathrm{P}_{2} \mathrm{O}_{5}\right.$ and $\left.\mathrm{Zn}\right)$ were applied immediately before the sowing of corn, considering that the dose of $\mathrm{Zn}$ applied $(2.0 \mathrm{~kg} / \mathrm{ha})$ was constant for all treatments.

The fertilizer used for the supply of $\mathrm{N}$ was monoammonium phosphate granules (MAP) and urea, and for the supply of P, MAP and triple superphosphate were used, according to the doses of each treatment. Zinc sulfate was the $\mathrm{Zn}$ source used.

Each plot of the experiment consisted of four double rows of plants with 6.0 $\mathrm{m}$ length, spacing of $1.40 \mathrm{~m}$, totaling an area of $33.6 \mathrm{~m}^{2}(6.00 \times 5.60 \mathrm{~m})$. The two center rows were considered as the plot useful area, $1.0 \mathrm{~m}$ in each borderline being discarded. Thus, the plot useful area measured $11.2 \mathrm{~m}^{2}(2.80 \times 4.00 \mathrm{~m})$.

\section{Cropping operations}

The conventional tillage was carried out, consisting of two crossed harrowings at an average depth of 20 $\mathrm{cm}$. The marking of planting lines 
was carried out using a trencher, at an average depth of $5 \mathrm{~cm}$. Then, the blocks and plots were marked, after being measured.

The implementation of the experiment was carried out in April, 2012. Corn was grown in double rows in the spacing of $1.40 \mathrm{~m}$ between the double rows, 0.40 between simple rows in the double row and $0.30 \mathrm{~m}$ between plants in the simple row, making a population of approximately 37,000 plants/ha. The sowing was carried out at an average depth of $2 \mathrm{~cm}$ with one seed per pit in the planting line. The hybrid used was AG-1051 (Agroceres).

During the field experiment, the rainfall was $49.5 \mathrm{~mm}$. Thus, due to frequent periods of drought in the region, complementary irrigation was carried out. Trickle irrigation system was used, with drip emitters spaced $0.40 \mathrm{~m}$, a flow rate of $1.7 \mathrm{~L} / \mathrm{h}$ under pressure of $120 \mathrm{kPa}$. The supplementary irrigation water depth for this experiment was obtained through water balance, considering the precipitation and the crop evapotranspiration (ETc), using daily information on the weather from a weather station located on the farm.

The average values of average, maximum and minimum temperatures, relative humidity and potential evapotranspiration, during the experiment were: $26.9^{\circ} \mathrm{C} ; 36.3^{\circ} \mathrm{C}$; $18.9^{\circ} \mathrm{C} ; 62 \%$ and $6.7 \mathrm{~mm} / \mathrm{day}$, respectively. The total water depth provided during the corn crop cycle was approximately $400 \mathrm{~mm}$, so that the crop suffered no drought.
The cultural practices used during the experiment followed the region farmer's current techniques. The weed control was carried out through herbicide application, Atrazine (500 g/L) and Tembotrione $(420 \mathrm{~g} / \mathrm{L})$, during phase V2 of the crop. Six sprayings were carried out with insecticides, Methomyl (215 $\mathrm{g} / \mathrm{L})$ and Clorantraniliprole (200 g/L) for controlling Spodoptera frugiperda in corn.

\section{Traits evaluated in soil and in plants}

At 81 days after emergence (DAE) of the sweet corn, composite soil samples were collected, at the depth of 0-20 cm from the useful area of each plot, for chemical analyses of total contents of $\mathrm{N}$, according to Tedesco et al. (1995), and contents of $\mathrm{P}$ through Mehlich-1 extraction (Embrapa, 2011). For obtaining the composite sample, two simple samples were collected in the furrow, four simple samples at $10 \mathrm{~cm}$ of the furrow and six simple samples at the midpoint between the furrows (Oliveira et al., 2007a).

At 56 DAE, with the beginning of the female inflorescence appearance, 10 plants of the useful area of each plot were collected, obtained at random, in the middle third of the opposite leaf and below the upper ear, excluding the midrib (Coelho, 2006), for chemical analyses of the contents of $\mathrm{N}$ and $\mathrm{P}$ (Tedesco et al., 1995).

At the end of the experiment with corn, at $77 \mathrm{DAE}$, the number and the weight of marketable unhusked green ears were evaluated in all the plants located in the useful area of each plot. The marketable unhusked green ears were considered those ones with adequate appearance for commercialization, it means, with no apparent evidences of pest attacks and with length greater than $23 \mathrm{~cm}$ (Silva et al., 2003). The number of ears per hectare was estimated based on the ears grown in the useful area of each plot.

Despite the fact that the authors had not carried out the economic analysis of the fertilization, the critical levels of $\mathrm{N}$ and $\mathrm{P}$ in plant and $\mathrm{P}$ in soil, for corn production, was estimated based on doses of maximum physical efficiency of $\mathrm{N}$ and $\mathrm{P}_{2} \mathrm{O}_{5}$ estimated for maximum productivity of corn. Therefore, these critical levels were obtained replacing values of $\mathrm{N}$ and $\mathrm{P}_{2} \mathrm{O}_{5}$ estimated in the adjusted regression equations. When the authors did not find any model adjustment, the average value of the nutrient observed was considered as the critical level.

\section{Statistical analyses}

Experimental data were submitted to analyses of variance and regression. For each variable evaluated, the authors sought the regression model that would best fit to the observed data. The regression model selection was carried out based on the values of $\mathrm{R}^{2}$ and on the significance of the model coefficient, using t-test up to $5 \%$ probability, the mean square of errors of the experiment general variance analysis being considered as the experimental error.

Table 1. Nitrogen and phosphorus content in plant and phosphorus in the soil, total number of ears (TNE), total weight of ears (TWE), total number (TNMUE) and weight (TWMUE) of marketable unhusked ears depending on nitrogen contents without phosphate fertilization (teores de nitrogênio e de fósforo na planta e de fósforo no solo, número (TNE) e peso total de espigas (TWE) e número (TNMUE) e peso total de espigas empalhadas comercializáveis (TWMUE), em função de doses de nitrogênio na ausência de adubação fosfatada). Chapada do Apodi, UFERSA, 2012.

\begin{tabular}{lccccccc}
\hline N dose (kg/ha) & $\begin{array}{c}\text { Plant N content } \\
\mathbf{( g / k g )}\end{array}$ & $\begin{array}{c}\text { Plant P content } \\
\mathbf{( g / \mathbf { k g } )}\end{array}$ & $\begin{array}{c}\text { P content in the } \\
\text { soil }\left(\mathbf{m g} / \mathbf{d m}^{3}\right)\end{array}$ & TNE & $\begin{array}{c}\text { TWE } \\
(\mathbf{k g} / \mathbf{h a})\end{array}$ & TNMUE & $\begin{array}{c}\text { TWMUE } \\
\mathbf{( k g} / \mathbf{h a})\end{array}$ \\
\hline 0 & 33.25 & 4.57 & 18.35 & 33,504 & 10,954 & 26,560 & 9,612 \\
45 & 32.27 & 4.75 & 15.12 & 35,876 & 12,339 & 32,173 & 11,696 \\
90 & 33.80 & 4.11 & 15.01 & 33,157 & 11,723 & 27,602 & 10,516 \\
\hline Mean & 33.10 & 4.48 & 16.16 & 34,179 & 11,672 & 28,778 & 10,608 \\
Linear effect & $\mathrm{ns}$ & $\mathrm{ns}$ & $\mathrm{ns}$ & $\mathrm{ns}$ & $\mathrm{ns}$ & $\mathrm{ns}$ & $\mathrm{ns}$ \\
Quadratic effect & $\mathrm{ns}$ & $\mathrm{ns}$ & $\mathrm{ns}$ & $*$ & $*$ & $*$ & $*$ \\
\hline
\end{tabular}

$\mathrm{ns}=$ not significant (não significativo); ${ }^{*}$ significant $(\mathrm{p}<5 \%$ ) (significativo a $5 \%$ de probabilidade). 
For the effect of $\mathrm{N}$ doses in the absence of $\mathrm{P}$, since they were just three points, the linear and quadratic effects of $\mathrm{N}$ doses were tested through $\mathrm{F}$ test, in the general variance analysis of the experiment.

\section{RESULTS AND DISCUSSION}

\section{Sweet corn yield}

The increase of $\mathrm{N}$ doses applied to the soil in the absence of phosphate fertilizer influenced significantly ( $5 \%$ probability level) the number and total weight of ears, and also the number and weight of marketable unhusked green ears (Table 1). The authors noticed quadratic behavior of data in relation to $\mathrm{N}$ doses applied; this fact highlighted that dose of $45 \mathrm{~kg} / \mathrm{ha} \mathrm{N}$ was the dose that provided the largest increments in all traits evaluated.

Responses related to $\mathrm{N}$ doses even in the absence of phosphate fertilizer may have occurred due to the soil of the experimental field, as $\mathrm{P}$ content was considered good $\left(15.20 \mathrm{mg} / \mathrm{dm}^{3}\right)$ according to Ribeiro et al. (1999), $\mathrm{P}_{2} \mathrm{O}_{5}$ fertilization being not necessary. These results show the residual effects of phosphorus fertilization on the melon crop, over ten years of cultivation, in the experimental field, which preceded corn planting. According to Khamprath (1987), the addition of $\mathrm{N}$ fertilizer promotes an increase in $\mathrm{P}$ absorption, even in soils with high levels of $P$, in which the addition of the latter has little effect.

In crop rotation or succession systems, when previous crops are properly fertilized, residual effects of phosphate fertilizers are remarkably expressed, and most of the times using phosphate fertilizers on the successor crops is not even necessary (Silva et. al., 2000). Studies on soils with high $\mathrm{P}$ retention capacity showed that, when they were properly treated with phosphate fertilizers, part of the nutrient remained in the soil, available to plants for several crops (Yost et al., 1981).

In experiments carried out in São Paulo under several conditions of soil, weather and crop system, Cantarella \& Raij (1986) verified that, generally, 70 to $90 \%$ of the experiment with corn

Table 2. Nitrogen and phosphorus contents in plant and phosphorus in the soil, total number (TNE) and weight (TWE) of ears and total number (TNMUE) and weight (TWMUE) of marketable unhusked ears depending on nitrogen contents with $40 \mathrm{~kg} / \mathrm{ha} \mathrm{P}_{2} \mathrm{O}_{5}($ teores de nitrogênio e de fósforo na planta e de fósforo no solo, número (TNE) e peso total de espigas (TWE) e número (TNMUE) e peso total de espigas empalhadas comercializáveis (TWMUE), em função de doses de nitrogênio na presença de $40 \mathrm{~kg} / \mathrm{ha}$ de $\mathrm{P}_{2} \mathrm{O}_{5}$ ). Chapada do Apodi, UFERSA, 2012.

\begin{tabular}{|c|c|c|c|c|c|c|c|}
\hline N dose (kg/ha) & $\begin{array}{c}\text { Plant } N \text { content } \\
(\mathrm{g} / \mathrm{kg})\end{array}$ & $\begin{array}{c}\text { Plant } P \text { content } \\
(\mathrm{g} / \mathrm{kg})\end{array}$ & $\begin{array}{l}P \text { content in the } \\
\text { soil }\left(\mathbf{m g} / \mathbf{d m}^{3}\right)\end{array}$ & TNE & $\begin{array}{c}\text { TWE } \\
\text { (kg/ha) }\end{array}$ & TNMUE & $\begin{array}{c}\text { TWMUE } \\
\text { (kg/ha) }\end{array}$ \\
\hline$\overline{0}$ & 33.69 & 4.46 & 25.16 & 34,025 & 11,691 & 29,164 & 10,848 \\
\hline 45 & 32.27 & 4.67 & 22.16 & 34,719 & 12,119 & 29,164 & 10,801 \\
\hline 90 & 31.83 & 3.96 & 21.57 & 33,330 & 12,004 & 29,511 & 11,320 \\
\hline 160 & 32.27 & 4.14 & 24.51 & 34,256 & 12,154 & 31,478 & 11,744 \\
\hline 220 & 31.39 & 4.57 & 22.89 & 33,157 & 12,468 & 30,205 & 11,952 \\
\hline Mean & 32.29 & 4.36 & 23.26 & 33,897 & 12,087 & 29,904 & 11,333 \\
\hline Regression $^{1}$ & NMA & NMA & NMA & NMA & NMA & NMA & NMA \\
\hline
\end{tabular}

${ }^{1} \mathrm{NMA}=$ No regression model adjusted to the data (nenhum modelo de regressão se ajustou aos dados).

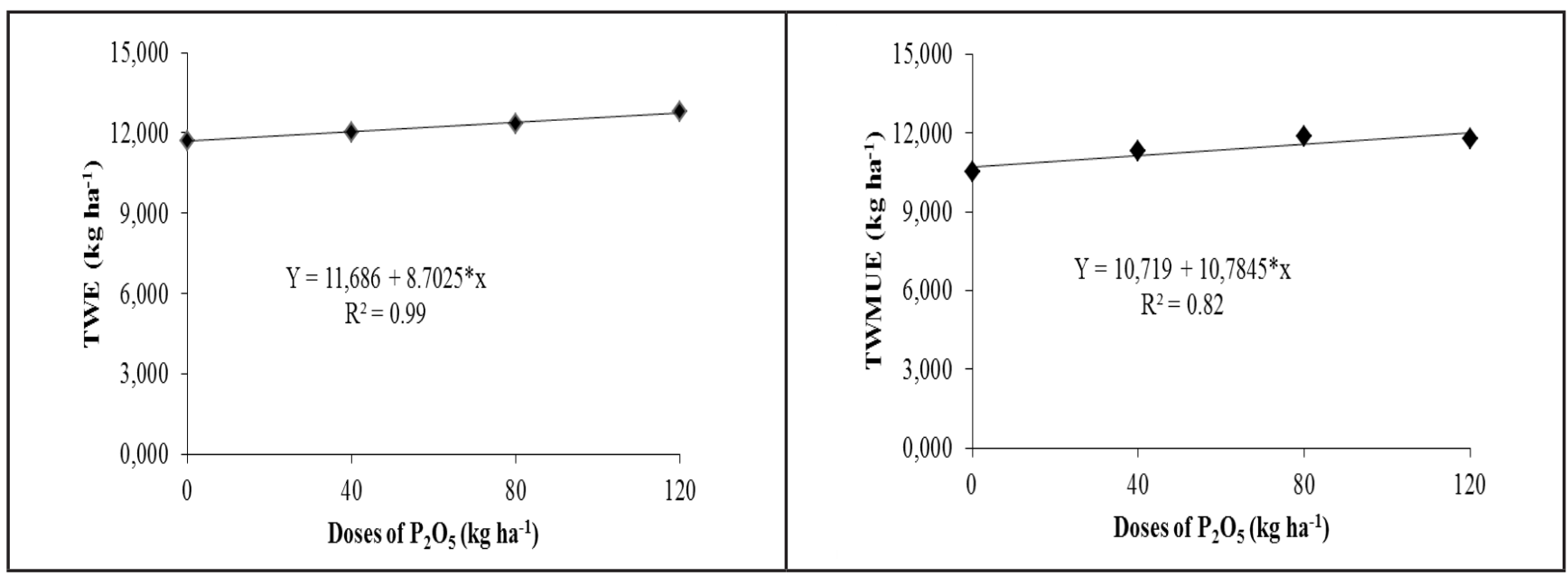

Figure 1. Total weight of ears (TWE) and weight of marketable unhusked ears (TWMUE) depending on $\mathrm{P}_{2} \mathrm{O}_{5}$ levels with $90 \mathrm{~kg} / \mathrm{ha} \mathrm{N}$; * significant at $\mathrm{p}<5 \%$ \{peso total de espigas (TWE) e peso de espigas empalhadas comercializáveis (TWMUE) de milho verde em função de doses de $\mathrm{P}_{2} \mathrm{O}_{5}$ na presença da dose de $90 \mathrm{~kg} / \mathrm{ha}$ de $\mathrm{N}$; *significativo a 5\% de probabilidade . Chapada do Apodi, UFERSA, 2012. 
Table 3. Nitrogen and phosphorus contents in plant and phosphorus in the soil, total number (TNE) and weight (TWE) of ears and total number (TNMUE) and weight (TWMUE) of marketable unhusked ears depending on phosphorus contents with $90 \mathrm{~kg} / \mathrm{ha} \mathrm{N}$ (teores de nitrogênio e de fósforo na planta e de fósforo no solo, número (TNE) e peso total de espigas (TWE) e número (TNMUE) e peso total de espigas empalhadas comercializáveis (TWMUE), em função de doses de fósforo na presença de $90 \mathrm{~kg} / \mathrm{ha} \mathrm{de} \mathrm{N)}$ ). Chapada do Apodi, UFERSA, 2012.

\begin{tabular}{|c|c|c|c|c|c|c|c|}
\hline $\begin{array}{l}\mathrm{P} \text { dose }\left(\mathrm{P}_{2} \mathrm{O}_{5}\right) \\
(\mathrm{kg} / \mathrm{ha})\end{array}$ & $\begin{array}{c}\text { Plant } N \text { content } \\
(\mathrm{g} / \mathrm{kg})\end{array}$ & $\begin{array}{c}\text { Plant } P \text { content } \\
(\mathrm{g} / \mathrm{kg})\end{array}$ & $\begin{array}{c}P \text { content in the } \\
\text { soil }\left(\mathbf{m g} / \mathbf{d m}^{3}\right)\end{array}$ & TNE & $\begin{array}{c}\text { TWE } \\
\text { (kg/ha) }\end{array}$ & TNMUE & $\begin{array}{c}\text { TWMUE } \\
\text { (kg/ha) }\end{array}$ \\
\hline 0 & 33.80 & 4.11 & 15.01 & 33,157 & 11,723 & 27,602 & 10,516 \\
\hline 40 & 31.83 & 3.96 & 21.57 & 33,330 & 12,004 & 29,511 & 11,320 \\
\hline 80 & 31.39 & 4.62 & 26.79 & 32,809 & 12,329 & 29,685 & 11,853 \\
\hline 120 & 33.80 & 4.57 & 28.34 & 35,240 & 12,775 & 30,379 & 11,777 \\
\hline Mean & 32.70 & 4.31 & 22.93 & 33,634 & 12,208 & 29,294 & 11,366 \\
\hline Regression $^{1}$ & NMA & NMA & UMA & NMA & UMA & NMA & UMA \\
\hline
\end{tabular}

${ }^{1} \mathrm{NMA}=$ no regression model adjusted to the data (nenhum modelo de regressão se ajustou aos dados); UMA= one model adjusted to the data (um modelo de regressão se ajustou aos dados).

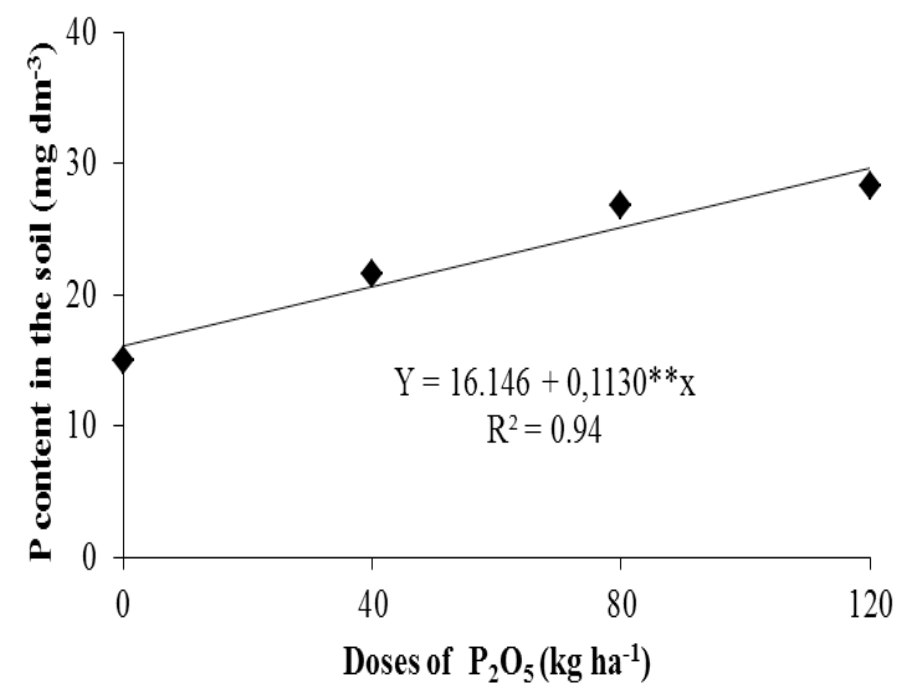

Figure 2. Phosphorus (P) levels in the soil depending on $\mathrm{P}_{2} \mathrm{O}_{5}$ fertilization with $90 \mathrm{~kg} / \mathrm{ha} \mathrm{N}$; **significant at $\mathrm{p}<1 \%$ \{teor de fósforo $(\mathrm{P})$ no solo em função de doses de $\mathrm{P}_{2} \mathrm{O}_{5}$ na presença da dose de $90 \mathrm{~kg} / \mathrm{ha}$ de nitrogênio; **significativo a $1 \%$ de probabilidade\}. Chapada do Apodi, UFERSA, 2012.

crop responded to $\mathrm{N}$ application. For Cantarella (1993), the magnitude of the responses to nitrogen in trials with corn crop, carried out in Brazil, has been variable, but most studies indicate positive responses to $\mathrm{N}$ doses from 30 to $90 \mathrm{~kg} / \mathrm{ha}$, due to, in part, relatively low levels of productivity.

Silva \& Silva (2003) studied the effect of splitting the recommended $\mathrm{N}$ dose in the same traits evaluated in the present research and verified higher yields when the total $\mathrm{N}$ dose was applied at 45 days after planting or when $1 / 3$ of the $\mathrm{N}$ dose was applied at 25 days after planting and the remaining $2 / 3$ at 45 days was adjusted to the data (Table 2). This fact highlights that discarding nitrogen fertilization and applying only $40 \mathrm{~kg} /$ ha $\mathrm{P}_{2} \mathrm{O}_{5}$ would be advantageous to the farmer, obtaining, in average, number and weight of marketable unhusked green ears equivalent to 29,904 units and 11,333 kg/ha, respectively (Table 2). These averages are higher than the values observed without $\mathrm{N}$ application in the absence of phosphate fertilizer (Table 1).

The variables total number of ears and number of marketable unhusked ears did not respond to phosphate fertilization in the presence of nitrogen fertilization $(90 \mathrm{~kg} / \mathrm{ha} \mathrm{N})$, since no regression model adjustment to the observed data was possible (Table 3). On the other hand, significant effects of $\mathrm{P}_{2} \mathrm{O}_{5}$ doses on the variables total and marketable unhusked ears weight was observed, being possible to adjust regression models to the data observed (Figures 1A; 1B). The regression model which best fitted the data both for total weight of ears and weight of marketable unhusked ears was the positive linear, it means that the highest total weight of ears and the highest weight of marketable unhusked ears in the presence of $90 \mathrm{~kg} / \mathrm{ha} \mathrm{N}$ was obtained with the dose of $120 \mathrm{~kg} / \mathrm{ha} \mathrm{P}_{2} \mathrm{O}_{5}$. et al. (2010) also verified increments in number and weight of marketable unhusked ears as a consequence of the increase of $\mathrm{N}$ doses applied to the soil.

Increasing doses of nitrogen in the soil in the presence of phosphate fertilizer did not provide effects on the traits evaluated, and no regression model
Contents of nitrogen and phosphorus in plant and phosphorus in the soil

The authors verified that despite not having found significant effect for contents of $\mathrm{N}$ in plants, these plants 
showed appropriate average contents of the nutrient for good development and production, even for the treatment with total absence of the nutrient $(\mathrm{N}=0)$ (Table 2), since according to Malavolta (2006) the appropriate content of $\mathrm{N}$, in corn leaves, for good development and production, is in the range from 28 to 35 $\mathrm{g} / \mathrm{kg}$ of dry matter. Araújo et al. (2004) also verified an increase of the $\mathrm{N}$ content in corn leaf with increasing doses of $\mathrm{N}$ applied to the soil. The authors also observed that, in the absence of phosphate fertilizer, the plants showed to be properly nourished in $\mathrm{P}$ showing contents in the sufficiency range (2.5-4.0 $\mathrm{g} / \mathrm{kg}$ ) (Table 3) indicated by Malavolta (2006), which possibly can be justified by the initial $\mathrm{P}$ content in the soil of the experimental field $\left(15.20 \mathrm{mg} / \mathrm{dm}^{3}\right)$.

The increase of phosphate doses in the presence of $90 \mathrm{~kg} / \mathrm{ha} \mathrm{N}$ influenced positive and significantly the content of $\mathrm{P}$ in the soil, but did not influence the contents of $\mathrm{N}$ and $\mathrm{P}$ in the plant (Table 3 ). The equation model which best adjusted to the data of $P$ in the soil was the positive linear (Figure 2). The increase of the content of $\mathrm{P}$ in the soil in the presence of nitrogen was also obtained by Silva et al. (2014). However, the increase of $\mathrm{P}$ content in the soil according to the doses of $\mathrm{P}_{2} \mathrm{O}_{5}$ applied, in the presence of nitrogen fertilizer, did not reflect in significant increase in nutrient concentration in the plant, which is possibly due to the effect of the dilution of the nutrient according to the greatest production of marketable unhusked ears.

Under this experiment conditions, the authors noticed that producing corn in succession to the growing of melon is possible without application of $\mathrm{N}$ and $\mathrm{P}$ to the soil. However, in order to obtain the maximum productivity of corn, the authors recommend application of 90 $\mathrm{kg} / \mathrm{ha} \mathrm{N}$ with $40 \mathrm{~kg} / \mathrm{ha} \mathrm{P}_{2} \mathrm{O}_{5}$. The average critical level of $\mathrm{N}$ and $\mathrm{P}$ in the plant to produce sweet corn was 32.29 and 4.31 $\mathrm{g} / \mathrm{kg}$, respectively, and for $\mathrm{P}$ in the soil was $20.7 \mathrm{mg} / \mathrm{dm}^{3}$.

\section{REFERENCES}

ARAUJO, LAN; FERREIRA, ME; CRUZ, MCP. 2004. Adubação nitrogenada na cultura do milho. Pesquisa Agropecuária Brasileira 39: 771-777.

CANTARELLA, H. 1993. Calagem e adubação do milho. In: BÜLL, LT. (ed) A cultura do milho: fatores que afetam a produtividade. Piracicaba: Potafos, p.147-185.

CANTARELLA, H; RAIJ, B. 1986. Adubação nitrogenada no Estado de São Paulo. In: SANTANA, MBM (Coord). Adubação nitrogenada no Brasil. Ilhéus: CEPLAC, SBCS p. 47-49.

COELHO, AM. 2006. Nutrição e adubação do milho. Sete Lagoas: Embrapa Milho e Sorgo. 10p. (Circular Técnica, 78).

EMBRAPA. 2011. Embrapa Comunicação para Transferência de Tecnologia. Manual de métodos de análises de solo (Brasília, DF): 2 ed. $230 \mathrm{p}$.

EMBRAPA. 2013. Centro Nacional de Pesquisa de Solos. Sistema Brasileiro de Classificação de Solos (Rio de Janeiro, RJ). 3 ed. 306p.

FERREIRA, HA; SOUZA, AS; SOUSA, DA; SOUZA, AS; MARACAJÁ, PB. 2010. Componentes de produção e produtividade do milho submetido a doses de nitrogênio no semiárido paraibano. Revista Verde de Agroecologia e Desenvolvimento Sustentável 5: 90-96.

FIDELIS, RR; MIRANDA, GV; ERASMO, EAL. 2009. Seleção de populações base de milho sob alta e baixa dose de fósforo em solo de cerrado. Pesquisa Agropecuária Tropical 39: 285-293.

FILGUEIRA, FAR. 1982. Manual de Olericultura: cultura e comercialização de Hortaliças São Paulo: Agronômica Ceres. 357p.

FILGUEIRA FAR. 2009. Novo Manual de Olericultura. Viçosa: UFV, 402p.

FRANCHINI, JC; COSTA, JM; DEBIASI, H; TORRES, E. 2011. Importância da rotação de culturas para a produção agrícola sustentável no Paraná. Londrina: (Embrapa Soja. Documentos, 327). 52p.

KAMPRATH, EJ. 1987. Enhanced phosphorus status of maize resulting from nitrogen fertilization of high phosphorus soil. Soil Science Society of America Journal. 51: 1522-1526.

MALAVOLTA, E. 2006. Manual de nutrição mineral de plantas. São Paulo: Agronômica Ceres. 638p.

OLIVEIRA, FHT; ARRUDA, JA; SILVA, IF; ALVES, JC. 2007a. Amostragem para avaliação da fertilidade do solo em função do instrumento de coleta das amostras e de tipos de preparo do solo. Revista Brasileira de Ciência do Solo 31: 973-983.

OLIVEIRA, JC; SILVEIRA, EB; MARIANO, RLR; CARDOSO, E; VIANA, IO. 2007b. Caracterização de Isolados de Acidovorax avenae subsp. citrulli. Fitopatologia Brasileira 32: 480-487.

RIBEIRO, AC; GUIMARÃES, PTG; ALVAREZ, VVH. 1999. Recomendações para o uso de corretivos e fertilizantes em Minas Gerais. Viçosa: CFSEMG. 359p.

SCUDELER, F; VENEGAS, F; CORDEIRO, RN. 2011. Avaliação técnica e econômica de fontes de nitrogênio em plantio e cobertura na cultura do milho (Zea mays L.). Ensaios e Ciências 15: 67-75.

SILVA, E; DE-POLLI, H; GUERRA, JGM; MENEZES, EA; RESENDE, ALS; OLIVEIRA, FL; RIBEIRO, RLB. 2011. Sucessão entre cultivos orgânicos de milho e couve consorciados com leguminosas em plantio direto. Horticultura Brasileira 29: 57-62.

SILVA, EC; SILVA FILHO, AV; ALVARENGA, MA. 2000. Efeito residual da adubação da batata sobre a produção do milho-verde em cultivo sucessivo. Pesquisa Agropecuária Brasileira 35: 2151-2155.

SILVA, GF; OLIVEIRA, FHT; PEREIRA, RG; SILVA, PSL; DIÓGENES, TBA; SILVA, ARC. 2014. Doses de nitrogênio e fósforo para produção econômica de milho na Chapada do Apodi RN. Revista Brasileira de Engenharia Agrícola 18: 1247-1254.

SILVA, PSL; OLIVEIRA, FHT; SILVA, PIB. 2003. Efeitos da aplicação de doses de nitrogênio e densidades de plantio sobre os rendimentos de espigas verdes e de grãos de milho. Horticultura Brasileira 21: 452- 55.

SILVA, PSL; SILVA, PIB. 2003. Parcelamento da adubação nitrogenada e rendimento de espigas verdes de milho. Horticultura Brasileira 21: 149-152.

TEDESCO, MJ; GIANELLO, C; BISSANI, CA; BOHNEM, H; VOLKWEISS, SJ. 1995. Análise de solo, plantas e outros materiais. Porto Alegre: UFRGS. (Boletim Técnico, 5). 2. ed. $174 p$.

YOST, RS; KAMPRATH, EJ; NADERMAN, GC; LOBATO, E. 1981. Residual effects of phosphorus applications on a high phosphorus adsorbing oxisol of Central Brazil. Soil Science Society of America 45: 540-543. 